\title{
Станислава Небжеговска-Бартминьска
}

\author{
Университет им. Марии Кюри-Склодовской \\ Люблин, Польша \\ stanislawa.niebrzegowska-bartminska@poczta.umcs.lublin.pl
}

\section{Крестьянский этос труда в системе связанных с ним ценностей}

В этнолингвистических исследованиях рефлексия над ценностями, их иерархией и взаимоотношениями является центральным элементом описания языковой картины мира. Реконструкция мира ценностей может быть осуществлена тремя различными, но дополняющими друг друга способами: а) путем изучения аксиологически наполненных жанров (сонник, пожелание, гороскоп); б) путем анкетных исследований, направленных на составление списка ценностей; в) путем семантического анализа ключевых для исследуемой культуры понятий. Первый подход предполагает поиск внутренней цели (интенции) жанра и высшей идеи, вписанной в текст. Второй подход апеллирует к знаниям носителей данной культуры и/или авторитету исследователя («эксперта») и его знакомству с определенной лингвокультурой. Третий подход основан на представлении о том, что понятия связаны системой взаимозависимостей, которые можно обнаружить путем анализа дефиниций. Последний тип исследований признается наиболее важным: он не только дает список и образ ценностей в выбранном жанре речи, но и демонстрирует систему взаимосвязей между ними, «погружает» отдельные ценности в богатые, поддерживающие и дополняющие друг друга культурно-языковые контексты.

Автор представляет результаты применения указанных исследовательских методов, сопоставляет их и эксплицирует ценности, наиболее близкие носителям народной культуры (земля, мать, дом), а также ценности, из которых складывается крестьянский этос (работа, справедливость, солидарность). Особое внимание уделяется анализу двух ключевых для крестьянской культуры концептов («земля», «работа»), выявляется их функционирование в системе ценностей: жизненных и материально-бытовых, общественно-нравственных и «чувственных», этических и религиозных, а также эстетических. В результате автор (C) Небжеговска-Бартминьска С., 2019 
получает систему аксиологических взаимосвязей земли и работы с другими ценностями, такими как жизнь, пища, плодородие, достаток, богатство, трудолюбие, удовлетворение, общественное признание, доверие, взаимодействие, взаимность, справедливость, равенство, солидарность, нравственный порядок, святость, Бог, уважение, достоинство, честь, традиция, музыка, красота - вплоть до родного края, локальной общности, вотчины, дома, матери, этнической родины и родной страны.

Пер. с польск. Е. О. Борисовой

DOI 10.31168/7996-2700-3.84

\author{
Александра Невяра \\ Силезский университет \\ Катовице, Польша \\ aleksandra.niewiara@us.edu.pl
}

\title{
Концепции коллективного времени как фактор польской идентичности
}

Коллективное время - это время, которое сообщество переживает вместе, а также время, которое хранится в коллективной памяти. Научные теории о коллективном времени (или социальном времени) и коллективной памяти возникли в социологических трудах в первой половине XX в. [Tarkowska, 1987; Saryusz-Wolska, Traba, 2014]. В наши дни их влияние распространилось на всю гуманитарную науку, не исключая этнолингвистику.

Этнолингвистические исследования могут описывать фольклорное и религиозное течение времени [Szadura, 2017, 253-297], но могут быть направлены на изучение этнической общности, которая воспринимает себя отдельно от других из-за своего языка, государства, страны, культуры, истории. Таким образом, мы можем говорить о времени поляков, русских, англичан или французов. Мы можем также, основываясь на текстах разных исторических периодов, наблюдать, как коллективное время представлялось в определенный период, и делать выводы о его эволюции. В докладе автор представит результаты анализа польских

(C) Невяра А., 2019 